\title{
Improvement Strategy in Virtual Education. An experience from Cuba
}

\author{
Alejandro García Figal ${ }^{1}$, Mariuska Sarduy Gonzáles ${ }^{2}$, Eliza Juverly Zambrano \\ Zambrano $^{3}$
}

\author{
${ }^{1,2}$ Faculty of Accounting and Finance, University of Havana, Cuba \\ ${ }^{3}$ Technical University of Manabí, Manabí, Ecuador
}

Received: 02 Jul 2021; Received in revised form: 03 Aug 2021; Accepted: 12 Aug 2021

(C2021 The Author(s). Published by TheShillonga. This is an open access article under the CC BY license (https://creativecommons.org/licenses/by/4.0/)

\begin{abstract}
The complex context through which the pandemic is passing is unknown to no one, the radical changes in the way of life of the human being in general have been dramatic and difficult to face. The educational process in Cuba has not been a factor unrelated to these conditions, and the need to make use of new technologies to transfer said process and impart it in a purely virtual way has been a common challenge. The empirical work aims to develop a training strategy in the didactics of virtual learning environments, an idea agreed between the members of the board of directors of the School of Accounting and Finance. Thus, begins a teaching movement that under the imprint of profound changes in the teaching process, on the one hand, involves the debate of ideas and methods, and, on the other.
\end{abstract}

Keywords - collaboration, digital information, digital platform, virtual education, virtual educational environments, virtualization.

\section{INTRODUCTION}

In the complex reality that is lived reality, it has been an imperative need to make use of new technologies and transfer the educational process to virtual spaces. The methodology on how to carry out such a task has been a factor of discussion by academics who seek to establish an easy, affordable, interactive and innovative process. Based on this need, the Directorate of Technological Development of the University of Havana creates a virtual teaching and learning environment (EVEA) using the free distribution platform Moodle, and allocates a space for each institution to take learning courses. where the university student can nurture and acquire knowledge, and not only acquire it, but put it into practice through case studies, exercises and workshops.

However, the strategy to apply when creating each course depends on the line drawn by the different faculties, and the professor in charge of said discipline. The subject is very important in a country where there has always been a high quality in higher education, and this quality is expected to be the same in this new modality of virtual study. Therefore, the need arises for a methodology that adjusts to this new context, that makes the most of new technologies, and provides high training to the university student. The purpose of the research is to propose a training strategy that guarantees these tasks based on the experiences that the School of Accounting and Finance of the University of Havana has had in this new context.

\section{METHODOLOGY}

Authors such as Cristóbal (2010), agree on the high capacity of the so-called "internet" to distribute and share information in real time, however, this does not remove the inconveniences that the network of networks presents when it is intended to use it in virtual education, some of these defects are related to the type of content and others related to technical aspects. It is not enough to provide the student with digitized information; the teacher has to ensure that such information will facilitate the acquisition of knowledge.

Studying traditional educational environments, a pattern of promoting individual work processes that follow a predefined work algorithm is detected: the teacher assigns 
an autonomous learning activity to the student. Authors such as Shuai, Matt, Marco, Honghao, Bing \& Alberto (2018), in their research "e-Learning, e-Education, and Online Training" argue that traditional education is the teaching-learning process in which teachers and students engage in They meet in the same space and time, defining this act as face-to-face education.

However, in virtual education, a new context is created where the learning process loses a good part of its social dimension (Karla \& María, 2012). The author agrees with Cristóbal \& Begoña (2012), where it is stated that learning, whether face-to-face or virtual, is not a solitary experience, but a substantially social one. This is argued in "Cooperative interaction: social condition of learning" by (Cristóbal, 2010), line of thought that the author follows in the empirical work.

Federico (2005), argues that, in virtual education, remote and asynchronous work limits the opportunities to obtain immediate feedback between students and teachers. The author presumes, therefore, that, in the virtual teaching process, there will be disenchantment and low motivation on the part of the student, this linked to the few options to interact or work with a partner or teacher.

Analyzing the above, there is a prevailing need to think about possible ways that seek to favor and stimulate learning in virtual teaching environments, always with a social perspective. Authors such as Rama (2016), propose a collaborative variant, with constant interaction between student and teacher, considering that the experiences promoted in virtual programs, developed under this training methodology, have been successful throughout the world.

Jeremy \& Stephanie (1995), defined "collaborating" as the continuous attempts to build and maintain a shared conception of the problem that result in a coordinated and symmetrical activity. On the other hand, Mizuho, Takashi, Tagiru \& Hiroaki (2014), define collaboration as effective and respectful work where different teams interact in order to achieve a common goal. The author assumes these definitions and intends to build a strategy that has collaboration as its core.

The illustrated work algorithm starts from collecting information on the opinions and results of this new teaching process at the School of Accounting and Finance of the University of Havana. The research methodology assumed combines the procedures and analysis of the quantitative and qualitative, on the basis of the relationship established between the theory, the method and the educational practice used. Equal relevance is given to both types of data, analyzing the information generated and determining its importance for the author's position. The strategy presented was organized on the basis of the following phases: diagnosis, planning, implementation and evaluation, considering the result of the diagnosis,

The didactic and functional methodology in the creation of a virtual course implies responding to the teaching requirements. When talking about virtual courses for studies in an institution where physical textbooks continue to constitute a basic learning tool, it is essential to ensure that the student receives said material transferred to a digital archive. In a teaching that is only supported by online resources, it is vitally important to provide the student with a series of didactic complements that fulfill a support purpose in this learning process, this through different tools and materials available on the virtual platform. This line of work was the one agreed in February 2021 by the management of the School of Accounting and Finance of the University of Havana.

Authors such as Fernando (2019), highlight the importance, in the creation and publication of a virtual course, of a close collaboration with the teacher and a multidisciplinary team made up of designers, programmers, virtualization specialists and experts in methodology, educational technology and didactic content. Following this methodology, a platform manager and work teams are appointed for each discipline, who work in conjunction with the technology department of the University of Havana.

\section{RESULTS}

The teaching process began by adapting the technological means to the needs of the disciplines, the teacher and the students. The virtualization of educational materials began, question banks, workshops, forums were created, and virtual tools and resources were added to automate tasks; This entire process considering the needs of the members involved, avoiding the vulgarity of making information devoid of knowledge available to the student.

Initially, in the School Board of Directors, a minimum structure was established that all courses had to comply with in order to ensure a logical sequence and homogenize the preparation of subjects as much as possible. A consensus was reached, seeking that the courses did not become simple repositories, but that there was constant feedback between teachers and students, as well as an active participation of the student in the platform, and increase their motivation for the study.

The main objective is the transmission of knowledge; therefore, it is imperative to provide a space where the bulk of the study material and the course planning are presented. The material must be organized and structured keeping in mind the criteria of integration, coherence and clarity. The student will be offered generic information on the course 
(teachers, syllabi, media, evaluation, etc.) and development of the topics that make up the program.

The first block (A) lasted six weeks, 13 subjects were taught in the daytime course, and 13 in course per meeting, the 26 subjects followed the following general structure:

1. Initial presentation

2. Student guide

3. General indications

4. Methodological instructions

a. Lessons

i. Teaching tools

5. Basic bibliography

6. Further reading

This structure was formed seeking to provide the student with a logical work algorithm that allows him to move through the subject in an easy and interactive way. Regarding the support tools provided by the virtual platform, training workshops were given to explain their use to the faculty, and it was left to the heads of disciplines which of these tools to apply in each course.

\subsection{Situation analysis}

After four weeks of block (A), a diagnosis is made by applying questionnaires, first to the students and then to the teachers.

- Day course, with an enrollment of 592 students, of these 564 enrolled and interacted with the virtual platform, giving a percentage of activity in the system of $95.27 \%$.

- Course per meeting with an enrollment of 456 students had a $93.42 \%$ (426 students) participation in the platform.

A survey was applied to the students of the faculty, yielding the following results:

Table 1: Students who have a device to ensure a stable connection

\begin{tabular}{lll}
\hline It has a device & $\begin{array}{l}\text { Has a device, but } \\
\text { shares it }\end{array}$ & $\begin{array}{l}\text { You don't have } \\
\text { a device }\end{array}$ \\
\hline $85.64 \%$ & $11.60 \%$ & $2.21 \%$ \\
\hline
\end{tabular}

Table 2: Used connection routes

\begin{tabular}{lll}
\hline Mobile data & Nauta Home & Wifi Etecsa \\
\hline $95.58 \%$ & $15.57 \%$ & $9.94 \%$ \\
\hline
\end{tabular}

Table 3: Difficulty level regarding access to the EVEA platform

\begin{tabular}{llll}
\hline Easy & Hard & Very easy & $\begin{array}{l}\text { Very } \\
\text { difficult }\end{array}$ \\
\hline $67.96 \%$ & $26.52 \%$ & $4.42 \%$ & $1.10 \%$ \\
\hline
\end{tabular}

Table 4: Studying time

\begin{tabular}{lllllll}
\hline 2 to & $\mathbf{4} 1$ to & $\mathbf{2}$ & $\begin{array}{l}\text { More } \\
\text { hours }\end{array}$ & $\begin{array}{l}\mathbf{4 - 6} \\
\text { hours } \\
\text { hours }\end{array}$ & $\begin{array}{l}\text { Up to 1 } \\
\text { hours }\end{array}$ & hour \\
\hline $29.28 \%$ & $25.97 \%$ & $17.13 \%$ & $14.36 \%$ & $12.15 \%$ \\
\hline
\end{tabular}

Table 5: Ways in which the student receives the information

\begin{tabular}{lll}
\hline EVEA platform & WhatsApp & Email \\
\hline $90.06 \%$ & $80.11 \%$ & $31.04 \%$ \\
\hline
\end{tabular}

Table 6: Means by which the student acquires the bibliography

\begin{tabular}{lll}
\hline EVEA platform & $\begin{array}{l}\text { Copy the digital } \\
\text { folder of the folder of the } \\
\text { subject through } \\
\text { a partner }\end{array}$ & $\begin{array}{l}\text { Cobject in the } \\
\text { faculty }\end{array}$ \\
\hline $94.48 \%$ & $17.13 \%$ & $5.52 \%$ \\
\hline
\end{tabular}

Table 7: Activities most used in virtual courses

\begin{tabular}{llll}
\hline $\begin{array}{l}\text { Multiple } \\
\text { choice } \\
\text { questions }\end{array}$ & $\begin{array}{l}\text { True or } \\
\text { false } \\
\text { questions }\end{array}$ & $\begin{array}{l}\text { Questionn } \\
\text { aires }\end{array}$ & $\begin{array}{l}\text { Pre- } \\
\text { designed } \\
\text { tasks }\end{array}$ \\
\hline $81.22 \%$ & $80.66 \%$ & $54.70 \%$ & $49.17 \%$ \\
\hline $\begin{array}{l}\text { Problem } \\
\text { resolution }\end{array}$ & $\begin{array}{l}\text { Discussion } \\
\text { forums }\end{array}$ & $\begin{array}{l}\text { Column } \\
\text { binding } \\
\text { activities }\end{array}$ & Projects \\
\hline $18.78 \%$ & $19.34 \%$ & $16.57 \%$ & $7.73 \%$ \\
\hline
\end{tabular}

Table 8: Opinions on evaluation activities

\begin{tabular}{|c|c|c|}
\hline $\begin{array}{l}\text { They require a } \\
\text { lot of } \\
\text { preparation }\end{array}$ & $\begin{array}{l}\text { It does not } \\
\text { motivate them }\end{array}$ & $\begin{array}{l}\text { They should be } \\
\text { designed more } \\
\text { attractively }\end{array}$ \\
\hline $49.17 \%$ & $34.81 \%$ & $34.25 \%$ \\
\hline $\begin{array}{l}\text { They do not } \\
\text { help them to } \\
\text { overcome }\end{array}$ & $\begin{array}{l}\text { Very clear } \\
\text { guidelines }\end{array}$ & $\begin{array}{l}\text { Very } \\
\text { interesting }\end{array}$ \\
\hline
\end{tabular}


Table 9: Frequency of evaluations

\begin{tabular}{lllll}
\hline $\begin{array}{l}\text { More } \\
\text { than } \\
\text { twice } \\
\text { week }\end{array}$ & $\begin{array}{l}\text { Biweekl } \\
\text { a }\end{array}$ & $\begin{array}{l}\text { Once a } \\
\text { week }\end{array}$ & $\begin{array}{l}\text { Once a } \\
\text { month }\end{array}$ & $\begin{array}{l}\text { Other } \\
\text { answers }\end{array}$ \\
\hline $56.91 \%$ & $14.36 \%$ & $11.05 \%$ & $11.05 \%$ & $11.60 \%$ \\
\hline
\end{tabular}

Table 10: Access to the EVEA platform

\begin{tabular}{llll}
\hline Stressful & Intermittent & Easy & $\begin{array}{l}\text { Expensiv } \\
\text { e }\end{array}$ \\
\hline $47.51 \%$ & $42.09 \%$ & $31.49 \%$ & $28.73 \%$ \\
\hline Permanent & Hard & $\begin{array}{l}\text { Welco } \\
\text { me }\end{array}$ & Relaxed \\
\hline $15.47 \%$ & $13.26 \%$ & $11.60 \%$ & $1.66 \%$ \\
\hline
\end{tabular}

Table 11: Access to the contents of the virtual courses

\begin{tabular}{lllrlr}
\hline If you have & $\begin{array}{l}\text { You have not } \\
\text { been able to }\end{array}$ been able to access & not \\
access & $\begin{array}{l}\text { access } \\
\text { contents of some } \\
\text { subjects }\end{array}$ & \\
& $4.42 \%$ & & $1.66 \%$
\end{tabular}

Table 11: Teacher-student exchange

\begin{tabular}{lllll}
\hline Regular & Bad & Good & $\begin{array}{l}\text { Very } \\
\text { good }\end{array}$ & Excellent \\
\hline $48.62 \%$ & $23.76 \%$ & $17.13 \%$ & $7.18 \%$ & $1.10 \%$ \\
\hline
\end{tabular}

Table 12: Reason for communication with the year coordinator teacher

\begin{tabular}{llll}
\hline $\begin{array}{l}\text { Get } \\
\text { informatio } \\
\text { n }\end{array}$ & $\begin{array}{l}\text { Platform } \\
\text { difficulties }\end{array}$ & $\begin{array}{l}\text { Doubts } \\
\text { about } \\
\text { content }\end{array}$ & $\begin{array}{l}\text { Guidance on } \\
\text { the subjects }\end{array}$ \\
\hline $41.99 \%$ & $40.88 \%$ & $40.88 \%$ & $39.23 \%$ \\
\hline $\begin{array}{l}\text { Advice on } \\
\text { the use of } \\
\text { the }\end{array}$ & $\begin{array}{l}\text { Better } \\
\text { Knowledge } \\
\text { about the } \\
\text { objectives of } \\
\text { the year }\end{array}$ & $\begin{array}{l}\text { Know the } \\
\text { objectives } \\
\text { of the }\end{array}$ & $\begin{array}{l}\text { Suggest } \\
\text { ideas } \\
\text { regarding } \\
\text { the design of } \\
\text { activities }\end{array}$ \\
\hline $16.57 \%$ & $14.36 \%$ & $11.60 \%$ & $7.73 \%$ \\
\hline
\end{tabular}

Table 13: Main difficulties that students have faced

\begin{tabular}{|c|c|c|c|c|}
\hline $\begin{array}{l}\text { Commun } \\
\text { ication } \\
\text { with } \\
\text { teachers }\end{array}$ & $\begin{array}{l}\text { Connect } \\
\text { ion }\end{array}$ & $\begin{array}{l}\text { Organiza } \\
\text { tion to } \\
\text { carry out } \\
\text { activities }\end{array}$ & $\begin{array}{l}\text { Enroll } \\
\text { ment }\end{array}$ & $\begin{array}{l}\text { Motivati } \\
\text { on for } \\
\text { virtual } \\
\text { educatio } \\
\text { n }\end{array}$ \\
\hline $61.88 \%$ & $58.01 \%$ & $50.83 \%$ & $\begin{array}{l}43.65 \\
\%\end{array}$ & $38.67 \%$ \\
\hline $\begin{array}{l}\text { Access to } \\
\text { the } \\
\text { platform }\end{array}$ & $\begin{array}{l}\text { Delivery } \\
\text { of } \\
\text { evaluati } \\
\text { ons }\end{array}$ & $\begin{array}{l}\text { Concentr } \\
\text { ation }\end{array}$ & $\begin{array}{l}\text { EVEA } \\
\text { registr } \\
\text { ation }\end{array}$ & $\begin{array}{l}\text { Particip } \\
\text { ation in } \\
\text { evaluatio } \\
\text { ns }\end{array}$ \\
\hline $32.04 \%$ & $24.31 \%$ & $21.55 \%$ & $\begin{array}{l}20.44 \\
\%\end{array}$ & $16.57 \%$ \\
\hline $\begin{array}{l}\text { Independ } \\
\text { ent study } \\
\text { skills }\end{array}$ & $\begin{array}{l}\text { Access } \\
\text { the } \\
\text { bibliogr } \\
\text { aphy }\end{array}$ & $\begin{array}{l}\text { Commun } \\
\text { ication } \\
\text { between } \\
\text { student }\end{array}$ & \multicolumn{2}{|c|}{ No difficulty } \\
\hline $15.24 \%$ & $4.36 \%$ & $3.87 \%$ & $2.21 \%$ & \\
\hline
\end{tabular}

The School of Accounting and Finance of the University of Havana has a staff of 34 professors, a survey was applied to them, which yielded the following results:

Table 15: Feedback with students

\begin{tabular}{llll}
\hline Good & Very good & Regular & Excellent \\
\hline $42.75 \%$ & $25.00 \%$ & $21.88 \%$ & $9.38 \%$ \\
\hline
\end{tabular}

Table 14: Reason for Communication with the student

\begin{tabular}{lllll}
$\begin{array}{l}\text { Answer } \\
\text { questio } \\
\text { ns }\end{array}$ & $\begin{array}{l}\text { Offer } \\
\text { guidanc } \\
\text { e on the } \\
\text { subject }\end{array}$ & $\begin{array}{l}\text { That } \\
\text { they } \\
\text { know } \\
\text { the } \\
\text { objectiv } \\
\text { es of the } \\
\text { subject }\end{array}$ & $\begin{array}{l}\text { Report of a } \\
\text { difficulty in } \\
\text { operating } \\
\text { the }\end{array}$ & $\begin{array}{l}\text { Ideas } \\
\text { for the } \\
\text { design } \\
\text { of } \\
\text { activitie }\end{array}$ \\
\hline $96.88 \%$ & $90.63 \%$ & $68.75 \%$ & $68.75 \%$ & s \\
\hline
\end{tabular}

Table 15: Opinion on the usefulness of the EVEA platform

\begin{tabular}{llll}
\hline $\begin{array}{l}\text { Totally } \\
\text { agree }\end{array}$ & Agree & $\begin{array}{l}\text { Strongly } \\
\text { disagree }\end{array}$ & $\begin{array}{l}\text { In } \\
\text { disagreement }\end{array}$ \\
\hline $53.13 \%$ & $37.50 \%$ & $6.25 \%$ & $3.13 \%$ \\
\hline
\end{tabular}


Table 16: Main difficulties that teachers have faced

\begin{tabular}{|c|c|c|c|c|}
\hline $\begin{array}{l}\text { Design } \\
\text { non- } \\
\text { face-to- } \\
\text { face } \\
\text { evaluati } \\
\text { ons }\end{array}$ & $\begin{array}{l}\text { Connect } \\
\text { ion } \\
\text { stability }\end{array}$ & $\begin{array}{l}\text { Underst } \\
\text { and how } \\
\text { the } \\
\text { platform } \\
\text { works }\end{array}$ & $\begin{array}{l}\text { Design } \\
\text { of the } \\
\text { subject }\end{array}$ & $\begin{array}{l}\text { The } \\
\text { methodo } \\
\text { logical } \\
\text { work }\end{array}$ \\
\hline $56.25 \%$ & $53.13 \%$ & $53.13 \%$ & $51.88 \%$ & $34.38 \%$ \\
\hline $\begin{array}{l}\text { Achieve } \\
\text { expected } \\
\text { results } \\
\text { from } \\
\text { students }\end{array}$ & $\begin{array}{l}\text { Commu } \\
\text { nication } \\
\text { with } \\
\text { students }\end{array}$ & $\begin{array}{l}\text { Access a } \\
\text { technolo } \\
\text { gical } \\
\text { device }\end{array}$ & $\begin{array}{l}\text { I have } \\
\text { not } \\
\text { faced } \\
\text { difficulti } \\
\text { es } \\
\text { during } \\
\text { this } \\
\text { course }\end{array}$ & \\
\hline $31.25 \%$ & $31.25 \%$ & $18.75 \%$ & $3.13 \%$ & \\
\hline
\end{tabular}

The results are analyzed and the following readings are reached:

At the beginning of the school year in this new study modality there was a high participation, with good levels of activity, exceeding $90 \%$, which means that the absence of significant interactivity was not a problem in the faculty.

The majority of students (more than 94\%) obtained the bibliography with materials designed for online education through the platform, so there is a high use of bibliography.

Both students and teachers believe that the interaction between them has not been optimal, so the feedback between teachers and students is classified as deficient.

The main difficulties considering the responses of both groups are, in the foreground, in the communication between students and teachers, this being selected by $61.88 \%$ of the student body, and by $31.25 \%$ of the faculty; In addition, there is the motivation of the student, and his role as manager of his knowledge. In the background are the aspects related to the interaction of the different activities and tools, linked to the fact that more than $50 \%$ of the teachers believe that the main problem they face is the design of the subject and the evaluations, and that It is difficult for them to use the platform $100 \%$. In a third plane is related to connection and technology, an aspect that will be left aside in the empirical work.

\subsection{Strategy}

These shortcomings, found in the course of the first block, are proposed to be resolved through a strategy that starts from the potentialities found, revealed by the researcher's experience as a university teacher, through the analysis of information and interviews with colleagues.
As part of the potentialities, a high motivation is detected, which indicates that the faculty is convinced of the importance of virtual teaching and the use of the EVEA platform in it.

There is a process of continuous training for university teachers, where participation and critical reflection in their training environment are focused, in an environment of collaboration and cooperation, training and permanent interaction. This enables the constant development of the teacher and the continuous improvement of his work as a designer of virtual courses.

The strategy proposal is divided into four phases:

- $\quad$ Phase 1: Diagnosis

- $\quad$ Phase 2: Training

- Phase 3: Implementation

- $\quad$ Phase 4: Evaluation

\subsubsection{Diagnosis}

The current state of the situation is analyzed, the needs and problems detected in the use of the virtual environment as a learning resource are made known. It seeks to sensitize and educate teachers in relation to the need for their training in virtual learning environments. It also seeks to sensitize and educate teachers based on change and the need to transform the teaching-learning process. Phase performed and illustrated above.

\subsubsection{Training}

In this phase, a training aimed at teachers is carried out on the platform and in the different methodologies to be followed, this is achieved through continuous training workshops and specialized conferences. Work sessions are developed that allow the teacher to characterize the virtual learning environment, based on reflective and proactive work encounters.

The potentialities of the virtual environment are identified, and meetings to explore the EVEA platform are held. Tools are designed and proposed that allow the pertinent integration in the teaching-learning process of the subjects taught by the teacher.

In this phase, all the actions that will be implemented later are planned, actions that are created from the main problems detected in the diagnosis, and that seek to minimize them.

In the illustrated case, it is proposed to apply the "forum" tool as a complement to the course contents as an aspect that allows greater feedback between students and teachers, allowing communication in real time, and the uploading of audio and video files in response to doubts, that they have a better assimilation by the contemporary student. In addition, the student will be provided with a private forum, space to 
work in groups, carry out practices or assignments, and send their proposals to the rest of the classmates.

In order to facilitate the association, interrelation and assimilation of the main concepts of the discipline studied, a catalog of terms and definitions (glossary tool) will be provided that is linked to the teaching materials presented in the course.

New content will be generated that comes out of the dynamics of the book, conference and presentation, to achieve an increase in student motivation.

As an evaluation method, case studies will be added that require the student to reason and generate solutions by himself, tools that should be replacing the classic evaluations of multiple-choice questions and true or false.

The importance of supporting and motivating students should not be forgotten. Offering support and trying to motivate them from a distance implies the use of the different resources offered by the course in a coherent, close, flexible and enthusiastic way. Students face not only a new subject, they will also have to adapt to the rhythm of the virtual course, and of course, to the new tools.

For conflict prevention it is convenient to have the course prepared for when students access it. During the first week the student will be welcomed through a didactic video of no more than 5 minutes, the first tips are included in the course and they are informed about the calendar and organization of the first forums. You should not wait for the student to discover the possibilities of the virtual course, if the course is presented enthusiastically, as well as transparent and practical, he himself will continue the experience with greater ease.

\subsubsection{Implementation}

In the third phase, the selected forms and planned activities are implemented, this through an interaction between the manager of the faculty, heads of departments and heads of disciplines.

This phase has a starting point, where the groups redesign the content of their corresponding disciplines. Then a moment of development, where the proposed tools and activities are added and made up. In this process, cognitive and discipline-specific skills are put into practice, as well as providing opportunities for transfer, practice, and construction.

Finally, the closing moment. A key moment where before making the courses visible, the heads of departments together with the manager check them and highlight the relevant aspects, as well as propose some recommendations.

\subsubsection{Evaluation}

In the evaluation phase, the effectiveness of the actions proposed and used is verified. A follow-up is given as a process that accompanies the implementation of the acquired knowledge. The actions of the different phases of the strategy are perfected, based on the results that are obtained.

This phase is developed as a process from a new diagnosis, so that a systematic evaluation of the state of transformation achieved in the virtual courses can be counted on.

The evaluation actions are conceived to be carried out as a process, through the preceding phases of the strategy; that is, the evaluation is applied from the diagnostic process itself.

The proposed strategy seeks to improve this modality of virtual education more and more. It aims to achieve perpetual development in the online teaching-learning process, through continuous training of the faculty, seeking an increasing acceptance by the student.

\section{CONCLUSION}

The resources available to the School of Accounting and Finance of the University of Havana make an effective online education model a reality; However, the ideal use of the medium depends on many factors, among which we can highlight the quality of the didactic content, the use of the tools that the virtual platform makes possible, the involvement and participation of the members involved in the teaching process, among others. In short, the integration of a didactic and functional model that guarantees open, flexible and meaningful learning in online training that will favor the growth and development of the university student.

The main problems encountered lie in the communication between student and teacher, in student motivation, and in the teacher's difficulties in creating virtual courses. Shortcomings that are very common in virtual education, however, through the application of timely strategies can be resolved.

The proposed strategy has four phases, starting from a diagnosis of the current situation, moving on to a training phase, then implementation and finally evaluation. This strategy is not limited to a single application, but can be used assiduously, each time seeking an improvement in the virtual teaching process.

\section{REFERENCES}

[1] Cristóbal, S. G. (2010). La interacción cooperativa: condición social de aprendizaje. Barcelona: UOC. 
[2] Cristóbal, S. G., \& Begoña. G. S. (2012). Aprender en red: De la interacción a la colaboración. Barcelona: UOC.

[3] Federico, B. (mayo de 2005). Digithum. Obtained from UOC web http://openaccess.uoc.edu/webapps/o2/bitstream/10609/842 05/2/536-13372-1-PB.pdf

[4] Fernando, B. (2019). Docencia Virtual. Kindle.

[5] Jeremy, R., \& Stephanie, D. T. (1995). Google Académico. Obtained from Scholar Google web site: https://citeseerx.ist.psu.edu/viewdoc/download?doi=10.1.1.4 $68.1385 \&$ rep=rep $1 \&$ type $=$ pdf

[6] Karla, F. F., \& María, B. (28 de Mayo de 2012). Dialnet. Obtained from Metodología PACIE en los ambientes virtuales de aprendizaje para el logro de un aprendizaje colaborativo: https://dialnet.unirioja.es/servlet/articulo?codigo $=4156135$.

[7] Mizuho, I., Takashi, M., Tagiru, N., \& Hiroaki, C. (Enero de 2014). Researchgate. Obtenido de Researchgate Web site: https://www.researchgate.net/publication/285082837_Colla borative_Learning_Using_Integrated_Groupware_A_Case_ Study_in_a_Higher_Education_Setting

[8] Rama, C. (octubre de 2016). Redalyc. Obtained from La fase actual de expansión de la educación en línea o virtual en América Latina: https://www.redalyc.org/pdf/373/37348529004.pdf

[9] Shuai, L., Matt, G., Marco, Z., Honghao, G., Bing, J., \& Alberto, B. (2018). e-Learning, e-Education, and Online Training. Shanghai: Springer. 